\title{
BRAIN PROTECTION AND ANTI-AMNESIC EFFECTS ASSESSMENT OF DATURA INNOXIA MILL. AQUEOUS EXTRACTS
}

\author{
PROSPER T. KINDA ${ }^{1,6}$, SAMSON GUENNÉ $^{1}$, TINDANO BASILE ${ }^{3}$, NOUFOU OUÉDRAOGO ${ }^{2}$, \\ MOUSSA COMPAORÉ ${ }^{1}$, BALÉ BAYALA ${ }^{3}$, WALTHER BILD ${ }^{4 *}$, ROMEO DOBRIN $^{4}$, \\ CONSTANTIN TRUS ${ }^{5}$, ALIN CIOBICA ${ }^{7}$, MARTIN KIENDREBÉOGO ${ }^{1}$
}

\author{
${ }^{1}$ Laboratory of Applied Biochemistry and Chemistry (LA.BIO.C.A), University Ouaga I Pr Joseph KI-ZERBO, 03 P.O. Box: 7021 \\ Ouagadougou 03, Burkina Faso \\ ${ }^{2}$ Institute for Research in Health Sciences (IRSS/CNRST), Department of Medicine and Traditional Pharmacopoeia (MEPHATRA-PH), \\ 03 P.O. Box: 7192 Ouagadougou 03, Burkina Faso \\ ${ }^{3}$ Laboratory of Animal Physiology, University Ouaga I Pr Joseph KI-ZERBO, 03 P.O. Box: 7021 Ouagadougou 03, Burkina Faso \\ 4 "Grigore T. Popa" University of Medicine and Pharmacy, 16 Universitatii Street, 700115, Iași, Romania \\ ${ }^{5}$ Department of Morphological and Functional Sciences, Faculty of Medicine, "Dunărea de Jos” University, Galați, Romania \\ ${ }^{6}$ Laboratory of Forensic Sciences, General Direction of National Police, 01 P.O. Box: 22 Ouagadougou 01, Burkina Faso \\ ${ }^{7}$ Department of Research, Faculty of Biology, "Alexandru Ioan Cuza” University; 11 Carol I Avenue, 700506, Iaşi, Romania
}

*corresponding author: walther.bild@umfiasi.ro

Manuscript received: March 2019

\begin{abstract}
Traditional plants are largely used in alternative medicine for many disorders treatment. However, some discussions regarding the safety of their usage exist. The present study aims to evaluate the anti-amnesic effect of Datura innoxia leaves aqueous extract, and the possible noxious impact of its use. Thus, there were evaluated the possible protective effects of the extract on the central nervous system, as well as its toxic effects, by using Wistar rats models and NMRI mice, respectively. The results are showing non-protective effects of the aforementioned extract in the behavioural tests, as well as in the levels of acetylcholinesterase, superoxide dismutase and catalase specific activity evaluation. Superoxide dismutase and catalase activity also suffered some significant decreases in the extract-treated rats. In addition, the toxicity results showed no mortality in acute and subacute evaluation. However, behavioural disturbance in Y maze and elevated plus maze tests were observed in all animals receiving acute toxicity doses $(2400$ and $3000 \mathrm{mg} / \mathrm{kg} \mathrm{b.w.).} \mathrm{Likewise,} \mathrm{for} \mathrm{the} \mathrm{subacute} \mathrm{study,} \mathrm{there}$ was a body weight lost, biochemical and haematological changes in the extract treated groups. In conclusion, this study suggests that $D$. innoxia leaves aqueous extracts do not show any anti-amnesic effect on scopolamine-induced memory impairment rats. It could be considered low toxic up to the dose level of $3000 \mathrm{mg} / \mathrm{kg} \mathrm{b}$.w. in oral acute use and at the dose level up to $400 \mathrm{mg} / \mathrm{kg}$ b.w. in oral subacute use. These results could be of interest for the further use of this extract in traditional or clinical medicine.
\end{abstract}

\section{Rezumat}

Plantele tradiționale sunt utilizate foarte frecvent în medicina alternativă pentru tratamentul multor patologii. Cu toate acestea, există o serie de discuții cu privire la siguranța utilizării acestora. Prezentul studiu își propune să evalueze efectul anti-amnezic al extractului apos de frunze de Datura innoxia și posibilul impact toxic al utilizării sale. Astfel, au fost evaluate posibilele efecte protectoare ale extractului asupra sistemului nervos central, precum și efectele sale toxice, folosind modele de şobolani Wistar și respectiv şoareci NMRI. Rezultatele au demonstrat absența efectului protector al extractului în testele de comportament, precum și asupra nivelurilor de acetil colinesterază, superoxid-dismutază și catalază. Activitatea superoxiddismutazei și catalazei au prezentat scăderi semnificative la șobolanii tratați. În plus, rezultatele testelor de toxicitate nu au demonstrat mortalitate în evaluare acută și subacută. Cu toate acestea, au fost observate tulburări de comportament în testul labirintului la toate animalele care au primit doze toxice ( 2400 și $3000 \mathrm{mg} / \mathrm{kg}$ corp). De asemenea, pentru studiul subacut, s-a înregistrat o pierdere în greutatea corporală, precum și modificări biochimice și hematologice în grupele tratate cu extract. În concluzie, acest studiu sugerează că extractul apos de frunze de D. innoxia nu are efect anti-amnezic asupra şobolanilor cu deficiențe de memorie induse de scopolamină. Poate fi considerat uşor toxic, până la nivelul unei doze de $3000 \mathrm{mg} / \mathrm{kg}$ corp în administrare orală acută și în doze de până la $400 \mathrm{mg} / \mathrm{kg}$ corp în administrare orală subacută. Aceste rezultate ar putea fi de interes pentru utilizarea în continuare a acestui extract în medicina tradițională sau clinică.

Keywords: Datura innoxia, neuroprotective, behaviour

\section{Introduction}

Solanaceae is one of the plant families reported to have potential therapeutic potential and used in the treatment of a wide range of diseases. However, the majority of these plants were previously described as having toxic effects and recommended to be used with caution [5]. The species of Datura genus were 
reported to contain toxic and psychotropic substances [38]. They are widely found in urban and rural areas and mostly abused by younger teens $[1,9]$. Datura innoxia is an important medicinal plant used for neuropsychiatric disorders treatment such as epilepsy, consciousness loss, insomnia and nerves diseases $[20,24]$. It is well known to contain important natural substances such as tropane alkaloids (atropine, scopolamine), essential oils, saponins, flavonoids, phenols, and cardiac glycosides [3, 6, 34]. Some of the chemical contents of this plant are well known to be toxic and act on the nervous system [23, 39]. In a previous survey in the traditional medicine of Burkina Faso, D. innoxia were indexed to be specifically used by the older (experienced) traditional healers [20]. This utilization is based on long-term experience, presuming potential psychotropic and noxious effects of this plant. In the aim to contribute to the further safe use of $D$. innoxia, the leaves aqueous extract was evaluated in animal models, for the anti-amnesic effect in order to support its traditional use, and the toxicity effect to estimate the noxious risk of its use.

\section{Materials and Methods}

Plant collection and preparation of extracts

Datura innoxia leaves were collected from natural habitats of Gampéla, in the central area of Burkina Faso. They were identified by botanists of the Plants Department of University of Ouaga I-Pr Joseph Ki Zerbo (Burkina Faso). Voucher specimens were deposited at the herbarium of the university having the identity number 16971 .

Twenty-five grams ( $25 \mathrm{~g}$ ) of dried powder were extracted with $500 \mathrm{~mL}$ of distilled water at $100^{\circ} \mathrm{C}$ for $30 \mathrm{~min}$. It was filtered using muslin cloth and centrifuged at $4000 \mathrm{rpm}$ for $10 \mathrm{~min}$. The supernatant was collected and lyophilized to dryness. The residue was weighed to obtain the extracted yield and it was kept at $4{ }^{\circ} \mathrm{C}$. Chemical

Scopolamine, monobasic sodium phosphate $\left(\mathrm{NaH}_{2} \mathrm{PO}_{4}\right)$, dibasic sodium phosphate $\left(\mathrm{Na}_{2} \mathrm{HPO}_{4}\right)$, ethylenediamine tetraacetic acid (EDTA), all solvents were of analytical grade and purchased from Sigma-Aldrich (Germany). Diazepam and tramadol used as reference substances were purchased from a local pharmacy.

Experimental animals

Wistar rats and NMRI (Naval Medical and Research Institute) mice, obtained from the animal house of University Ouaga I Pr Joseph KI-Zerbo were used. The animals were housed for a week under controlled conditions for acclimatization before the experiments. The anti-amnesic study was performed with male adult rats weighing 237 - 383 g. Female adult mice weighing $25-28 \mathrm{~g}$ for acute toxicity and $26-34 \mathrm{~g}$ for subacute toxicity study were used. Animals were kept in plastic cages under identical animal house conditions and provided with standard pellet and water ad libitum. Twelve-hour light and dark alternate cycles (started at 6:00 a.m.) were provided, temperature was maintained at $22 \pm 3^{\circ} \mathrm{C}$ and relative humidity was $50 \pm 10 \%$. Rats and mice were treated in accordance with the guidelines of animal bioethics from the Act on Animal Experimentation and Animal Health and Welfare Act from Burkina Faso (Ethics committee acceptance CE-UOI-2018-03) and all procedures were in compliance with the European Council Directive of 24 November 1986 (86/609/EEC). All evaluations were performed between 9 a.m. and 16 p.m.

\section{The anti-amnesic evaluation}

Drugs administration

This study was conducted according to Hritcu's group method [15]. Drugs were daily prepared and administered by oral route for 14 consecutive days. The rats were randomized into four groups $(n=6)$. The $1^{\text {st }}$ group (Control) and the $2^{\text {nd }}$ group ( $\mathrm{Sco}$ ) received saline solution $(\mathrm{NaCl} 0.9 \%)$. The group 3 (DiL+Sco) received $D$. innoxia leaves extract (100 mg/kg b.w.) and the group 4 (Dzp+Sco) received diazepam (1.5 mg/kg b.w.). The $14^{\text {th }}$ day, all groups excepted control received scopolamine hydrobromide $(0.7 \mathrm{mg} / \mathrm{kg}$ b.w., by intraperitoneal route) $1 \mathrm{~h}$ after drug administration. Behavioral tests were performed $30 \mathrm{~min}$ after scopolamine administration. The anti-amnesic effect of extracts was estimated. $Y$-maze task

This test estimates the short-term memory through the spontaneous alternation behaviour [15]. The used Y-maze consisted of three arms (35 cm long, $25 \mathrm{~cm}$ high and $10 \mathrm{~cm}$ wide) and an equilateral triangular central area. Rats were placed at the end of one arm and allowed to move freely through the maze for 8 min. An arm entry was counted when the hind paws of the rat were completely within the arm. Spontaneous alternation behaviour was defined as entry into all three arms on consecutive choices. The number of maximum spontaneous alternation behaviours was then the total number of arms entered minus 2 . The spontaneous alternation (\%) was calculated as (actual alternations/maximum alternations) $\times 100$. Spontaneous alternation behaviour is considered to reflect spatial working memory, which is a form of short-term memory.

Elevated plus-maze test

This test was used to evaluate memory according to a procedure previously described $[12,17]$. The used elevated plus maze consisted of two open arms (49 $\mathrm{cm} \times 10 \mathrm{~cm})$ and two covered arms $(49 \mathrm{~cm} \times 10 \mathrm{~cm} \times$ $30 \mathrm{~cm}$ ), elevated to a height of $50 \mathrm{~cm}$ from the floor. On the first day, each rat was placed at the end of an open arm, facing away from the central platform. The transfer latency (TL) was defined as the time taken by the animal to move from the open arm into one of the covered arms with all its four legs. TL was recorded on the first day (i.e., $14^{\text {th }}$ day of drug administration) for each animal. The rat was allowed to explore the maze for 2 minutes and then returned to its home cage. Retention of this learned-task (memory) was estimated 
$24 \mathrm{~h}\left(15^{\text {th }}\right.$ day $)$ after the first day trial. The significant reduction in TL value of retention indicated an improvement in memory.

Brain enzymes activity assays

Supernatant preparation

After the Y-maze behavioural test, rats were decapitated and whole brains were removed. The hippocampal and cortical regions of each rat were carefully excised, weighted and homogenized (10\%) in ice-cold potassium phosphate buffer $(0.1 \mathrm{M}, \mathrm{pH} 7.4)$. The homogenate was centrifuged at $1000 \mathrm{x} \mathrm{g}$ for $15 \mathrm{~min}$ and the supernatant was used for AChE, SOD and CAT activity assays.

Acetylcholinesterase (AChE) activity assay

The AChE activity of rat brain homogenate was evaluated according to the method of Ellman [13] slightly adapted. In the principle of the reaction, acetylcholinesterase hydrolyses the substrate ATCI (acetylthiocholine iodide) to thiocholine and acetate, unstained products. Thiocholine in the presence of DTNB (5,5'-dithiobis-2-nitrobenzoic acid) gives a yellow product (5-thio-2-nitrobenzoate), which allows to follow the kinetics by spectrophotometry. For this test, $20 \mu \mathrm{L}$ of homogenate was introduced into each microplate well containing $150 \mu \mathrm{L}$ of phosphate buffer $(0.1 \mathrm{M}$, $\mathrm{pH}$ 8), $10 \mu \mathrm{L}$ of ATCI (14 mM) and $10 \mu \mathrm{L}$ of DTNB (10 mM). The absorbance of the yellow solution was measured at $412 \mathrm{~nm}$ every minute interval for $5 \mathrm{~min}$ using an UV/visible spectrophotometer.

Superoxide Dismutase (SOD) activity assay

The activity of superoxide dismutase (SOD) was assayed using the method of Misra and Fridovich [26] with slight modifications. It is based on the inhibition of autoxidation of epinephrine to adrenochrome. This oxidation has a very complex chemical mechanism, but several of its steps are $\mathrm{O}_{2}^{-}$dependent, and thus it can be used for SOD measurement. The rat brain supernatant $0.5 \mathrm{~mL}$ was added to distilled water 0.8 $\mathrm{mL}$, ice cold ethanol $0.25 \mathrm{ml}$ and chloroform $0.15 \mathrm{~mL}$. The mixture was shaken for 5 minutes at $4{ }^{\circ} \mathrm{C}$ and then centrifuged. $0.2 \mathrm{~mL}$ of EDTA $(0.6 \mathrm{mM}), 0.4$ $\mathrm{mL}$ of $\mathrm{Na}_{2} \mathrm{CO}_{3}(0.25 \mathrm{M})$ and $0.2 \mathrm{~mL}$ of epinephrine ( $3 \mathrm{mM})$ were added to the reaction mixture and the absorbance was measured at $420 \mathrm{~nm}$.

Catalase (CAT) activity assay

The CAT activity was measured according to the method of Beers and Siezer [8]. For this trial, $50 \mu \mathrm{L}$ of rat brain homogenate is introduced into a tube containing $950 \mu \mathrm{L}$ of phosphate buffer $(50 \mathrm{mM}, \mathrm{pH}$ 7.4). The reaction is initiated by the addition of 500 $\mu \mathrm{L}$ of hydrogen peroxide $\left(\mathrm{H}_{2} \mathrm{O}_{2}, 30 \mathrm{mM}\right)$. The control consisted to $1 \mathrm{~mL}$ of phosphate buffer and $500 \mu \mathrm{L}$ of hydrogen peroxide $\left(\mathrm{H}_{2} \mathrm{O}_{2}\right)$. The reduction of the optical density (OD) due to the decomposition of the hydrogen peroxide is measured after one minute of incubation at $240 \mathrm{~nm}$. The enzyme activity is expressed as $\mu \mathrm{mol}$ of $\mathrm{H}_{2} \mathrm{O}_{2}$ consumed $/ \mathrm{min} / \mathrm{mg}$ of protein.
Toxicity effect assessment

Acute toxicity study

The acute toxicity study was conducted under OECD 423 guidelines [29] with slight modifications. The mice were randomized into three groups and each group contained six animals. The $1^{\text {th }}$ group (Control) received saline solution $(\mathrm{NaCl} 0.9 \%)$, the $2^{\text {nd }}$ and the $3^{\text {rd }}$ group received $D$. innoxia leaves extract dose of $(2400 \mathrm{mg} / \mathrm{kg}$ b.w.) and (3000 mg/kg b.w.) respectively. After extract administration, the animals were observed continuously for the first 4 hours to detect eventual behavioural changes. Then, they were observed periodically for 72 hours for any mortality. Animals were maintained and weighed during the next two weeks. At the end of the study, mice were sacrificed by cerebral dislocation and organs (liver, spleen, kidney, lung, heart and brain) were removed, weighed and observed for possible morphological changes.

Subacute toxicity study

Subacute toxicity was performed in accordance with OECD 407 guidelines [30]. Animals were randomized into four groups $(n=6)$. The control and extracts were administrated by oral route for 28 consecutive days. Group 1 - 3 received $D$. innoxia leaves extract doses of 100,200 and $400 \mathrm{mg} / \mathrm{kg}$ b.w. respectively. The control group received saline $(\mathrm{NaCl} 0.9 \%)$. All animals were observed twice daily for mortality or behavioural changes. Animal's body weight was recorded the first day and at weekly intervals during the study, then the weight gain was calculated. At the end, the blood samples of each animal were collected by cardiac puncture for biochemical and haematological evaluation. Afterwards, mice were sacrificed and organs were removed, weighed and observed for eventual morphological changes.

Biochemical analyses were performed in serum obtained after centrifugation of total blood in tubes without anticoagulants. Creatinine (Creat), aspartate aminotransferase (AST), alanine aminotransferase (ALT), urea, total triglycerides (Tgly) and total Cholesterol (CholT) were evaluated in serum. Haematological analyses were performed in total blood collected in tubes with EDTA. The relative blood indices as white blood cell count (WBC), red blood cell count (RBC), haemoglobin $(\mathrm{Hb})$, haematocrit $(\mathrm{HCT})$, mean corpuscular haemoglobin concentration (MCHC), platelets (PLT), mean platelet volume (MPV) were assessed.

Statistical analysis

The statistical analysis was performed with GraphPad Prism 5.03 for Windows (Graph Pad Software, Inc., California USA), using One-way ANOVA. All results were expressed as the mean \pm S.E.M. Statistical differences were determined by Tukey's post hoc test for multiple intergroup comparisons in behavioural assessments, and Dunnett's test for comparisons with control group were used in the toxicity parameters studies. Differences were considered significant when the $\mathrm{p}$ value was less than $0.05(\mathrm{p}<0.05)$. 


\section{Results and Discussion}

\section{Anti-amnesia effect estimation}

This activity was assessed in the Y-maze task and the elevated plus maze test. The first trial evaluates the short-term memory of the animals. From the obtained results, the scopolamine group (Sco) showed a significant decrease $(p<0.05)$ of the spontaneous alternation (SA) as compared to the control group. The diazepam group (Dzp+Sco) showed a more significant decrease $(\mathrm{p}<0.01)$ of SA. These results indicate a difficulty for animals to remember the arm immediately explored before the current arm (arm from which it is going out), which suggested a short-term memory deficit. For the rats pre-administered with $D$. innoxia leaves extracts (DiF+Sco), the SA decreasing was observed, but no significance was noticed when compared to normal or scopolamine group (Figure 1A).

In the elevated plus maze test it was evaluated the memory of rats 24 hours after scopolamine administration. The Latency Time (TL) was recorded on the $14^{\text {th }}$ day (30 min after scopolamine treatment) and the $15^{\text {th }}$ day (24 $\mathrm{h}$ after scopolamine treatment). Animals receiving scopolamine alone, as well as those pre-administered with diazepam and $D$. innoxia extract, showed a significantly increase $(\mathrm{p}<0.01)$ of the TL at the $15^{\text {th }}$ day compared to the control group (Figure 1B). This result indicates a memory deficit in these animals [12].
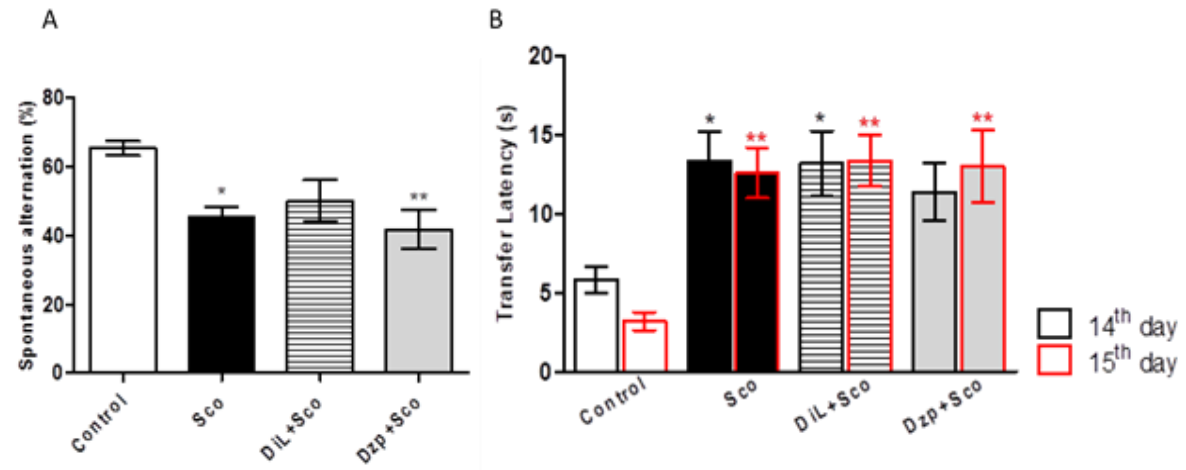

Figure 1.

Effect of D. innoxia leaves aqueous extract on Spontaneous Alternation [A], and Transfer Latency [B] of rats $* \mathrm{p}<0.05, * * \mathrm{p}<0.01$ compared with the control group

Brain's enzymes (AChE, SOD and CAT) activities evaluation

The AChE specific activity estimated in the rat brain homogenates, revealed no statistical difference $(\mathrm{p}>0.05)$ between all treated groups and the control group. Then, D. innoxia extract and diazepam pre-treated group showed no difference when compared to scopolamine alone group. However, AChE activity in all treated groups slightly tended to increase as confronted to control group (Figure 2a).
In the oxidative evaluation, all treated animals registered a decreasing SOD and CAT activity decreasing compared to control. The extract pre-treated group presented a significant reduction $(\mathrm{p}<0.05)$ of SOD activity and CAT activity; as compared to the control group (Figure $2 \mathrm{~b}$ and $2 \mathrm{c})$. Diazepam group recorded catalase activity decreasing $(p<0.01)$ when confronted to control group (Figure 2c).
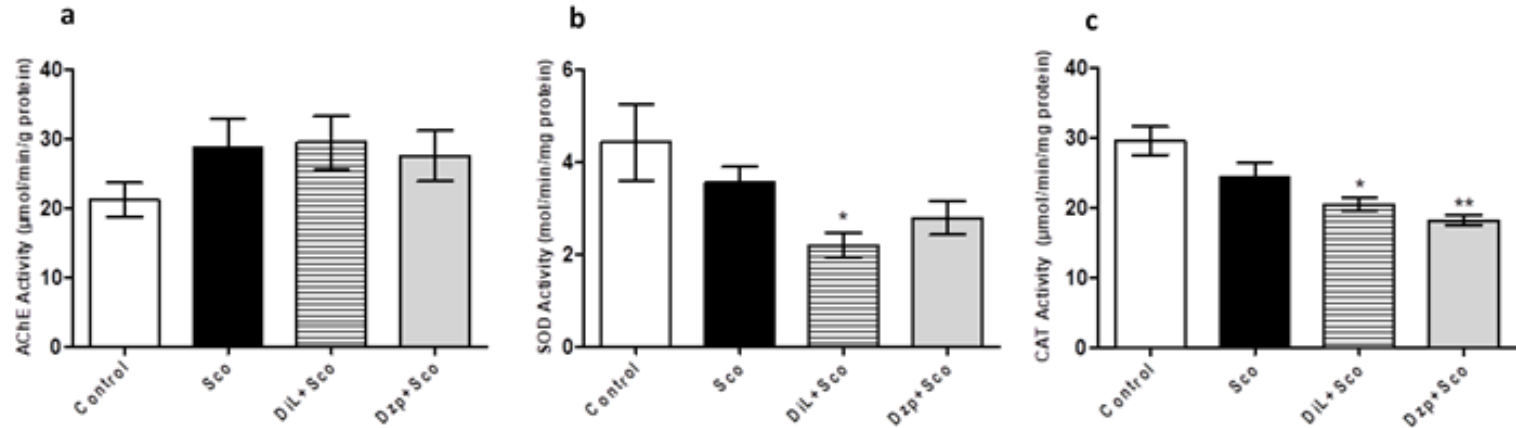

Figure 2.

Effect of D. innoxia leaves aqueous extract on AChE activity [a], SOD activity [b] and CAT activity [c] in rat brains $* \mathrm{p}<0.05, * * \mathrm{p}<0.01$ compared with the control group 
Acute toxicity effects of extract

In the acute toxicity assessment, there were no animal deaths, no changes in the appearance of internal organs both in groups receiving the extract at the dose of 2400 $\mathrm{mg} / \mathrm{kg} \mathrm{b}$.w. and of $3000 \mathrm{mg} / \mathrm{kg} \mathrm{b}$.w. as compared to control group. The mice body weight and relative organ weight were significantly changed (Table I). However, about 30 min after administration, all mice in the two extract treated groups were presented hypermobility and agitation movements. These active movements were continued for about 45 minutes.

\begin{tabular}{ccccc}
\hline Parameters & & Extract dose $\mathbf{2 4 0 0} \mathbf{~ m g} / \mathbf{k g} \mathbf{b . w}$. & Extract dose 3000 $\mathbf{~ g / k g ~ b . w . ~}$ & Control group \\
\hline \multirow{2}{*}{ Body weight } & $1^{\text {st }}$ day & $25.98 \pm 0.25$ & $26.73 \pm 0.14$ & $28.09 \pm 0.27$ \\
$(\mathbf{g})$ & $7^{\text {th }}$ day & $28.27 \pm 0.19$ & $29.18 \pm 0.13$ & $30.9 \pm 0.24$ \\
& $1^{\text {th }}$ day & $28.43 \pm 0.56$ & $30.28 \pm 0.52$ & $32.73 \pm 0.06$ \\
\hline & Liver & $3.63 \pm 0.36$ & $3.75 \pm 0.44$ & $4.57 \pm 0.29$ \\
Organs weight & Spleen & $0.39 \pm 0.03$ & $0.35 \pm 0.01$ & $0.44 \pm 0.05$ \\
$(\%)$ & Kidney & $0.81 \pm 0.08$ & $0.93 \pm 0.04$ & $1.15 \pm 0.07$ \\
& Lung & $0.71 \pm 0.07$ & $0.72 \pm 0.06$ & $0.79 \pm 0.08$ \\
& Heart & $0.49 \pm 0.07$ & $0.37 \pm 0.01$ & $0.4 \pm 0.02$ \\
& Brain & $1.16 \pm 0.11$ & $1.33 \pm 0.07$ & $1.36 \pm 0.03$ \\
\hline
\end{tabular}

Subacute toxicity effects of extract

Effect of plant extract on external parameters

No mortality was observed in all extract dose treated groups during 28-days period. Likewise, no noticeable changes in the general behaviour and relative organs weight of the animals were observed. Animal's body weight measures show a decrease in all extract treated groups. Dunnet's post hoc test revealed significant body weight loss in $100 \mathrm{mg} / \mathrm{kg}$ b.w. dose group $(\mathrm{p}<0.05)$ the $3^{\text {rd }}$ week, in $200 \mathrm{mg} / \mathrm{kg}$ b.w. dose group ( $<<0.01$ and $\mathrm{p}<0.05$ ) the $3^{\text {rd }}$ and the $4^{\text {th }}$ week respectively when comparing the body weight gain between treated groups and control group (Table II).

Effect of plant extract on biochemical and haematological parameters

The results of biochemical tests are presented in Table III. Significant decreases of creatinine (Creat) $(p<0.001)$ and alanine aminotransferase (ALT) ( $\mathrm{p}<0.05$ to $\mathrm{p}<0.001)$ were observed in all extract doses treated groups as compared to control group. The total cholesterol level (CholT) decreased $(\mathrm{p}<0.01)$ in the group receiving an extract dose of 200 $\mathrm{mg} / \mathrm{kg}$ b.w. and urea increased in the group receiving an extract dose of $400 \mathrm{mg} / \mathrm{kg}$ b.w. group. No significant changes were observed on aspartate aminotransferase (AST) and total triglycerides (Tgly) activity and level.

The haematological estimation in the extract treated groups showed an increase of assessed parameters except platelet (PLT) and mean platelet volume (MPV) which were low when compared to the control group. This increase was statistically significant for WBC $(\mathrm{p}<0.01)$ in the group receiving an extract dose of $400 \mathrm{mg} / \mathrm{kg}$ b.w., for $\mathrm{Hb}(\mathrm{p}<$ 0.01 and $p<0.05$ respectively) in groups received 100 and $400 \mathrm{mg} / \mathrm{kg}$ b.w., for RBC ( $<<0.01$ and $\mathrm{p}<0.05$ respectively) in groups received 100 and $200 \mathrm{mg} / \mathrm{kg} \mathrm{b.w.}$ and for MCHC ( $p<0.001$ and $p<0.05$ respectively) in groups received 100 and $400 \mathrm{mg} / \mathrm{kg}$ b.w. of extract. However, there was a significant decrease of MPV ( $p<0.001$ and $p$ $<0.05$ ) in groups administered with 200 and $400 \mathrm{mg} / \mathrm{kg}$ b.w. respectively. No significant changes were observed for the platelet (PLT) rate (Table III).

Table II

Weekly body weight $(\mathrm{g})$ and relative organs weight (\%) after four weeks

\begin{tabular}{cccccc}
\hline \multirow{2}{*}{ Parameters } & & \multicolumn{3}{c}{ D. innoxia leaves extract } & Control \\
& & $\mathbf{1 0 0} \mathbf{~ m g / k g ~ b . w . ~}$ & $\mathbf{2 0 0} \mathbf{~ m g / k g ~ b . w . ~}$ & $\mathbf{4 0 0} \mathbf{~ m g} / \mathbf{k g ~ b . w .}$ & group \\
\hline \multirow{5}{*}{ Body weight } & $1^{\text {st }}$ day & $32.16 \pm 0.38$ & $31.35 \pm 0.58$ & $26.62 \pm 0.55$ & $33.65 \pm 0.39$ \\
& $7^{\text {th }}$ day & $30.76 \pm 0.51$ & $29.98 \pm 0.66$ & $26.25 \pm 0.39$ & $33.35 \pm 0.38$ \\
& $14^{\text {th }}$ day & $31.37 \pm 0.52$ & $30.07 \pm 0.71$ & $26.47 \pm 0.35$ & $33.38 \pm 0.55$ \\
& $21^{\text {th }}$ day & $30.36 \pm 0.53$ & $29.47 \pm 0.70$ & $26.05 \pm 0.39$ & $33.51 \pm 0.23$ \\
& $28^{\text {th }}$ day & $31.26 \pm 0.69$ & $29.84 \pm 10.70$ & $26.25 \pm 0.36$ & $33.83 \pm 0.23$ \\
\hline \multirow{3}{*}{ Body weight gain } & $7^{\text {th }}$ day & $-4.26 \pm 2.46$ & $-4.40 \pm 0.59$ & $-1.33 \pm 1.04$ & $0.00 \pm 1.46$ \\
$(\%)$ & $14^{\text {th }}$ day & $-2.37 \pm 2.34$ & $-4.13 \pm 0.87$ & $-0.47 \pm 1.19$ & $0.08 \pm 1.78$ \\
& $21^{\text {th }}$ day & $-5.54 \pm 2.25^{*}$ & $-6.04 \pm 0.62^{*}$ & $-2.074 \pm 1.07$ & $0.51 \pm 1.34$ \\
& $28^{\text {th }}$ day & $-2.69 \pm 2.92$ & $-4.84 \pm 0.97 *$ & $-1.30 \pm 1.11$ & $1.46 \pm 1.47$ \\
\hline \multirow{5}{*}{ Organs weight } & Liver & $3.98 \pm 0.15$ & $4.08 \pm 0.18$ & $4.29 \pm 0.06$ & $3.91 \pm 0.27$ \\
& Spleen & $0.4 \pm 0.04$ & $0.68 \pm 0.26$ & $0.39 \pm 0.04$ & $0.41 \pm 0.03$ \\
& Kidney & $1.12 \pm 0.04$ & $1.11 \pm 0.05$ & $1.03 \pm 0.06$ & $1.16 \pm 0.04$ \\
& Lung & $0.52 \pm 0.03$ & $0.64 \pm 0.02$ & $0.74 \pm 0.08$ & $0.61 \pm 0.04$ \\
& Heart & $0.36 \pm 0.02$ & $0.4 \pm 0.01$ & $1.04 \pm 0.45$ & $0.55 \pm 0.11$ \\
& Brain & $1.14 \pm 0.10$ & $1.06 \pm 0.02$ & $1.28 \pm 0.05$ & $1.04 \pm 0.02$ \\
\hline
\end{tabular}


Table III

Extract effect on biochemical and haematological parameters

\begin{tabular}{|c|c|c|c|c|c|}
\hline \multirow{2}{*}{ Tests } & \multirow{2}{*}{ Parameters } & \multicolumn{3}{|c|}{ D. innoxia leaves extract } & \multirow{2}{*}{ Control group } \\
\hline & & $100 \mathrm{mg} / \mathrm{kg}$ b.w. & $200 \mathrm{mg} / \mathrm{kg}$ b.w. & $400 \mathrm{mg} / \mathrm{kg}$ b.w. & \\
\hline \multirow{6}{*}{ Biochemical } & Creat $(\mu \mathrm{mol} / \mathrm{L})$ & $34.8 \pm 4.25^{* * *}$ & $28.73 \pm 1.34 * * *$ & $29.3 \pm 4.63 * * *$ & $53.45 \pm 4.18$ \\
\hline & ALT (UI/L) & $44.2 \pm 0.45^{* *}$ & $37.42 \pm 1.14 * * *$ & $48.78 \pm 8.04 *$ & $63.85 \pm 1.87$ \\
\hline & AST (UI/L) & $190.03 \pm 19.81$ & $244.9 \pm 10.45$ & $257 \pm 9.29$ & $223.84 \pm 33.12$ \\
\hline & Urea (mmol/L) & $7.16 \pm 0.24$ & $6.55 \pm 0.22$ & $8.07 \pm 0.58^{*}$ & $6.59 \pm 0.39$ \\
\hline & Tgly (mmol/L) & $2.355 \pm 0.54$ & $1.87 \pm 0.25$ & $2.18 \pm 0.50$ & $2.34 \pm 0.15$ \\
\hline & CholT $(\mathrm{mmol} / \mathrm{L})$ & $3.47 \pm 0.21$ & $2.52 \pm 0.37 * *$ & $3.54 \pm 0.23$ & $3.73 \pm 0.08$ \\
\hline \multirow{7}{*}{ Haematological } & WBC $\left(10^{9} / \mathrm{L}\right)$ & $2.17 \pm 0.15$ & $1.97 \pm 0.21$ & $2.87 \pm 0.11 * *$ & $1.9 \pm 0.29$ \\
\hline & $\mathrm{Hb}(\mathrm{g} / \mathrm{dL})$ & $14.85 \pm 0.59 * *$ & $13.65 \pm 0.09$ & $14.28 \pm 0.12 *$ & $12.62 \pm 0.54$ \\
\hline & $\operatorname{RBC}\left(10^{12} / \mathrm{L}\right)$ & $8.95 \pm 0.30 * *$ & $8.95 \pm 0.05^{*}$ & $8.62 \pm 0.05$ & $7.92 \pm 0.31$ \\
\hline & НCТ (\%) & $43.5 \pm 1.9$ & $42.83 \pm 0.48$ & $43.23 \pm 0.19$ & $40.42 \pm 1.61$ \\
\hline & $\operatorname{MCHC}(\mathrm{g} / \mathrm{dL})$ & $34.2 \pm 0.60^{* * *}$ & $31.83 \pm 0.14$ & $32.98 \pm 0.16^{*}$ & $31.45 \pm 0.28$ \\
\hline & $\operatorname{PLT}\left(10^{9} / \mathrm{L}\right)$ & $499.3 \pm 110.2$ & $513 \pm 36.51$ & $470.5 \pm 6.91$ & $639.8 \pm 4.60$ \\
\hline & MPV (fL) & $7.7 \pm 0.12$ & $5.9 \pm 0.09 * * *$ & $6.45 \pm 0.215^{*}$ & $7.07 \pm 0.17$ \\
\hline
\end{tabular}

Creatinine (Creat), Aspartate aminotransferase (AST), Alanine aminotransferase (ALT), Urea, Total triglycerides (Tgly) and total Cholesterol (CholT). White Blood cells (WBC), Red Blood cells (RBC), Haemoglobin (Hb), Haematocrit (HCT), Mean Corpuscular Volume (MCV), Mean Corpuscular Haemoglobin Concentration (MCHC), Platelets (PLT), Mean Platelet Volume (MPV)

The first part of the present study aimed to examine D. innoxia leaves aqueous extract impact on the scopolamine-induced memory deficit on rats. The data recorded in the Y-maze task and the elevated plus maze test showed that the intraperitoneal injection of scopolamine causes memory impairment, in accordance with previous investigations [12, 19]. These results suggest that $D$. innoxia extract produces no protective effects against scopolamine induced rat memory impairment. Acetylcholine is an important neurotransmitter which has a role in the enhancement of memory and sensory perception [14, 15, 19]. Acetyl cholinesterase (AChE) enzyme catalyses acetylcholine hydrolysis causing its decrease in the brain. Thus, scopolamine-induced memory deficit is an appropriate model for the study of the cholinergic system dysfunction [15]. Our results indicated that the rat brain AChE activity was lightly increased but not significantly as well on scopolamine alone group as the extract and diazepam treated groups. This result is in accordance with the behavioural tests data, sustaining memory impairment induction in all treated rats. Previous studies support that memory impairment induced by scopolamine is related to oxidative stress indices, and alter SOD and CAT specific activities [7, 32]. SOD and CAT represents an important enzyme family able to protect the biological integrity of the cells and tissues against harmful effects of superoxide free radicals [31]. The decreases of the SOD and CAT activities observed in the treated groups corroborate with previous works [7, 15] and the spontaneous alternation (SA) and transfer latency (TL) values in our behavioural studies. In the extract pre-treated animals like in the diazepam group, these antioxidant enzymes activity decrease was emphasized compared to scopolamine group, suggesting a prooxidative or stress induced effect. Diazepam is a mild anticholinergic according to the classification of anticholinergic drugs [25]. It induces amnesia in laboratory animals [15, 28]. Likewise, $D$. innoxia leaves extract was reported to contain tropanic alkaloids including scopolamine and hyoscyamine [10]. These literature data could explain the fact that diazepam and $D$. innoxia extract have accentuated the amnesia and oxidative stress induced by scopolamine. All the results of these evaluations demonstrate the non-neuroprotective effect of $D$. innoxia leaves extract.

$D$. innoxia is well known to contain substances with a wide range of biological properties. Some of these properties are beneficial and used in treating many diseases, but some others are reported to have harmful effects [6]. The toxicological evaluation of this study showed no mortality after a single dose administration of extract up to the dose level of $3000 \mathrm{mg} / \mathrm{kg} \mathrm{b.w}$. This result suggests that the aqueous extract is safe or low toxic [29]. It agrees with the results of [2] who reported that $\mathrm{LD}_{50}$ of $D$. innoxia leaves aqueous extract by oral route was $3200 \mathrm{mg} / \mathrm{kg}$ b.w., but it is different from the results of Kutaifa's group [22] who obtained a LD $502400 \mathrm{mg} / \mathrm{kg}$ b.w. During our evaluation, it was observed animal's behavioural changes after extract administration both at the dose of 2400 and $3000 \mathrm{mg} / \mathrm{kg}$ b.w. The hyper-mobility and agitation reflect locomotor activity increasing. These behavioural changes might be due to mice CNS stimulation or hallucinogenic effect induced by some chemical content of $D$. innoxia, known to possess these properties [23, 39]. The subacute toxicity study revealed no mortality and no behavioural changes in the treated groups during the 28-day period. While animals body weight usually decreased, significant body weight loss were observed in extract treated groups after three weeks of administration. Reductions in the body weight of animals in toxicity studies may be associated with normal physiological adaptation responses to the plant extracts or compounds, which lead to a low appetite. Likewise high or accumulation 
doses of plant extracts or compounds might also induce stress in the animals, thereby reducing their food intake, which may lead to their body weight decrease $[4,35]$. For some authors, body weights increase or decrease are associated with toxic effects of drugs [18]. In the biochemical tests, significant decreases of Creat ( $\mathrm{p}<0.001)$ and ALT ( $<<0.05$ to $\mathrm{p}<0.001)$ were noticed in all extract treated groups as compared to the control group. Creatinine is a product of the metabolism of creatine, which is produced in the liver and stored in muscle to be used as a source of energy once phosphorylated. It is eliminated in urine by kidneys. Its level rise in the serum is an indicator of damage in the renal function [21]. Meanwhile, the creatinine level decreasing could indicate myopathy or damage of the liver function [37]. The transaminases (AST and ALT) are well-known enzymes used as good indicators of liver function and serve as biomarkers predicting possible toxicity [27]. Changes of these enzymes levels in serum could be linked to liver damage or some cellular injuries [21]. ALT is quoted to be a sensitive and specific marker predicting hepatic cells damage. Elevated serum levels of ALT might depict liver disease, myopathy or serious rhabdomyolysis [11]. In short, the Creat and ALT levels change observed in the treated groups might be caused by eventual harmful effects of extract on liver or other organs cells. In the haematological evaluation, significant increases were observed in $\mathrm{WBC}, \mathrm{RBC}, \mathrm{Hb}$, and MCHC levels in at least one extract dose groups as compared to the control group. Elevated erythrocyte indices can be used as potential indicators of developing vascular complications, the toxic compound exposure or some organ damage [16]. PLT and MPV were decreased in the treated animals and significant values were recorded for MPV in groups receiving extract doses of 200 and $400 \mathrm{mg} / \mathrm{kg} \mathrm{b.w}$. The hematopoietic system is one of the most sensitive targets for toxic compounds and an important index of physiological and pathological status in humans and animals [9]. Thus, the extract might affect the thrombopoiesis and produce harmful effects. These results agree with previous studies reporting that $D$. innoxia contains tropane alkaloids $[33,40]$ which have toxic effects on biochemical and haematological parameters [9].

Some of these aspects could also have an increased relevance in the context of the potential therapeutical value of some plant extracts in the current pathologies and their related complications $[22,36]$.

These results of the toxicological evaluation suggest that $D$. innoxia leaves aqueous extract is non-lethal at single dose level up to $3000 \mathrm{mg} / \mathrm{kg}$ b.w. However, it produces some behavioural disturbing effects. Likewise, in the case of multiple consecutive doses, it produces some toxic effects on animal's body weight and internal parameters.

\section{Conclusions}

The present investigation provides many information about $D$. innoxia leaves extract toxicity and its behavioural effects on mice. Administered (100 mg/kg b.w.) for two weeks, this plant extract revealed no neuroprotective activity against scopolamine-induced amnesia on rats. Then, $D$. innoxia aqueous extract was found to be no-lethal at a single dose up to $3000 \mathrm{mg} / \mathrm{kg}$ b.w. by oral route, but induces behavioural disturbances. It could also have noxious effects in the case of repeated administration from the dose of $100 \mathrm{mg} / \mathrm{kg}$ b.w. These results could be of interest for the further use of this extract in traditional or clinical medicine.

\section{Acknowledgement}

This work was financially supported by UEFISCDI Romania, project no PN-III-P1.1-TE2016-1210, contract no. 5 from 02/05/2018.

\section{Conflict of interest}

The authors declare no conflict of interest.

\section{References}

1. Abdelouahab B, Nadia M, Nabila K, Acute toxicity study of Datura stramonium seeds in rat. Roavs, 2011; 1(7): 434-440.

2. Ange AA, Landry M, Alain M, Jean M, Neuropsychopharmacologocal effects of leaves and seeds extracts of Datura fastusa. Asian Net Sci Inf., 2004; 3 (2): 109-113.

3. Aripova SF, Yunusov SY, Phytochemical investigation of Datura innoxia. Bioorganicheskaya Khimiya, 1989; 1: 36-38.

4. Arsad SS, Esa NM, Hamzah H, Othman F, Evaluation of acute, subacute and subchronic oral toxicity of Rhaphidophora decursiva (Roxb.) Schott extract in male Sprague Dawley rats. J Med Plants Res., 2013; 7(41): 3030-3040.

5. Aubry P, Intoxications par les plantes toxiques dans les zones tropicales et inter tropicales. Tropic Med., 2012; 1-11.

6. Ayuba VO, Ojobe TO, Ayuba SA, Phytochemical and proximate composition of Datura innoxia leaf, seed, stem, pod and root. J Med Plants Res., 2011; 5(14): 2952-2955.

7. Bagci E, Aydin E, Mihasan M, Maniu C, Hritcu L, Anxiolytic and antidepressant-like effects of Ferulago angulata essential oil in the scopolamine rat model of Alzheimer's disease. Flavour Fragr J., 2015; 31 : 70-80.

8. Beers F, Sizer JR, Cambridge, a spectrophotometric method for measuring the breakdown of hydrogen peroxide by catalase. J Biol Chem., 1951; 195: 133-140.

9. Benouadah Z, Mahdeb N, Bouzidi A, Evaluation of acute and sub-acute toxicity of alkaloids from Datura stramonium sp. in mice. IJPPR, 2016; 8(11): 1759-1766.

10. Berkov S, Zayed R, Comparison of tropane alkaloid spectra between Datura innoxia grown in Egypt and Bulgaria. Z Naturforsch., 2004; 59c: 184-186. 
11. Buswell L, Giostra E, Stalder H, Elevation des transaminases (aminopeptidases). $1^{\text {ere }}$ edition, $\mathrm{n}^{\circ} 25$. 2001, www.hcuge.ch.

12. Desai AB, Kagathara VG, Joshi H, Rangani AT, Mungra $\mathrm{H}$, Evaluation of antiamnesic effect of solasodine in mice. Int $J$ PharmTech Res., 2011; 3(2): 732-740.

13. Ellman GL, Courtney KD, Andres V, Feathe-Stone $\mathrm{RM}$, A new and rapid colorimetric determination of acetylcholinesterase activity. Biochem Pharmacol., 1961; 7: 88-95.

14. Handra C, Coman OA, Coman L, Enache T, Stoleru S, Sorescu AM, Ghită I, Fulga I, The connection between different neurotransmitters involved in cognitive processes. Farmacia, 2019; 67(2): 193-201.

15. Hritcu L, Bagci E, Aydin E, Mihasan M, Antiamnesic and antioxidants effects of Ferulago angulata essential oil against scopolamine-induced memory impairment in laboratory rats. Neurochem Res., 2015; 40: 1799 1809.

16. Jabeen F, Rizvi HA, Aziz F, Wasti AZ, Hyperglycemic induced variations in hematological indices in type 2 diabetics. Int J Adv Res., 2013; 1(8): 322-334.

17. Joshi H, Parle M, Evaluation of the antiamnesic effects of Phyllanthus amarus in mice. Colomb Med., 2007; 38(2): 132-139.

18. Kifayatullah M, Mustafa MS, Sengupta P, Sarker MMR, Das A, SDas K, Evaluation of the acute and sub-acute toxicity of the ethanolic extract of Pericampylus glaucus (Lam.) Merr. in BALB/c mice. J Acute Disease, 2015; 4(4): 309-315.

19. Kim D, Lee SH, Hong JH, Lillehoj HS, Park HJ, Rhie SG, Lee GS, The butanol fraction of Eclipta prostrata (Linn) increases the formation of brain acetylcholine and decreases oxidative stress in the brain and serum of cesarean-derived rats. Nutrition Research., 2010; 30: 579-584.

20. Kinda PT, Zerbo P, Guenné S, Compaoré M, Ciobica A, Kiendrebeogo M, Medicinal plants used for neuropsychiatric disorders treatment in the Hauts Bassins region of Burkina Faso. Medicines, 2017: 4(32): 1-21.

21. Kripa KG, Chamundeeswari D, Thanka J, Acute and sub-acute toxicity evaluation of ethanolic extract of Leucas aspera (Lamiaceae) in experimental rats. Int J Drug Dev \& Res., 2011; 3(3): 339-347.

22. Kutaifa MAA, Abbas DA, Kadhim FM, Acute toxicity of aqueous and petroleum ether extracts of Datura innoxia leaves in mice. Al-Anbar J Vet Sci., 2012; 5(2): 68-74.

23. Loumé L, Souffle du diable: quel est l'effet de la «drogue des voleurs» sur le cerveau? Sciences et avenir, 2015, www.sciencesetavenir.fr.

24. Maheshwari NO, Khan A, Chopade BA, Rediscovering the medicinal properties of Datura sp.: A review. $J$ Med Plants Res., 2013; 7(39): 2885-2897.

25. Mebarki S, Trivalle C, Échelles d'évaluation de l'effet anticholinergique des médicaments. NeurologiePsychiatrie-Gériatrie, 2012; 12: 131-138.

26. Misra HP, Fridovich I, The role of superoxide anion in the autoxidation of epinephrine and a simple assay for superoxide dismutase. J Biol Chem., 1972; 247(10): 3170-3175.

27. Mukinda JT, Eagles PFK, Acute and sub-chronic oral toxicity profiles of the aqueous extract of Polygala fruticosa in female mice and rats. J Ethnopharm., 2010; 128: 236-240.

28. Nikolaev SM, Nikolaeva IG, Razuvaeva YG, Matkhanov IE, Tsybiktarova LP, Shantanova LN, Nikolaeva GG, Phenolic compound of Serratula centauroides and anxolytic effects. Farmacia, 2019, 67(3): 504-510.

29. Organisation for Economic Cooperation and Development (OECD). Test Guideline 423. Acute Oral Toxicity Acute Toxic Class Method. In: OECD Guidelines for the Testing of Chemicals, 2001.

30. Organisation for Economic Cooperation and Development (OECD). Test Guideline 407. Repeated Dose 28-day Oral Toxicity Study in Rodents. In OECD Guidelines for the Testing of Chemicals, 2008.

31. Otitoju O, onwurah INE, Otitoju GTO, Ugwu CE, Oxidative stress and superoxide dismutase activity in brain of rats fed with diet containing permethrin. Biokemistri, 2008; 20(2): 93-98.

32. Padurariu M, Balmuș M, Ciobică A, Lefter R, Cojocaru S, Antioch I, Foyet H, Dobrin R. Ababei DC, Bild V, Oxytocin administration, improves memory anxiety and some oxidative stress parameters in a methionine induced rat model of schizophrenia. Farmacia, 2018; 66(3): 421-431.

33. Plank KH, Wagner KG, Determination of hyoscyamine and scopolamine in Datura innoxia plants by high performance liquid chromatography. Z. Naturforsch., 1986; 41c: 391-395.

34. Preeti, Narayan M, Meena HR, Studies on the antibacterial and phytochemical activity of Datura innoxia. Bioved., 2015; 26(2): 317-321.

35. Rhiouani HR, Nazari P, Kamli-Nejad M, Lyoussi B, Acute abd subchronic oral toxicity of an aqueous extract of leaves of Herniaria glabra in rodents. $J$ Ethnopharm., 2008; 118: 378-386.

36. Guenné S, Balmus I-M, Hilou A, Ouattara N, Kiendrebéogo M, Ciobica A, Lefter R, Poroch V, Timofte D, The relevance of Asteraceae family plants in most of the neuropsychiatric disorders treatment. Internat $J$ Phytomed., 2016; 8 (2): 176-182.

37. Slack A, Yeoman A, Wendon J, Renal dysfunction in chronic liver disease. Critical Care, 2010; 14: 1-10.

38. Stafford GI, Jäger AK, van Staden J, African psychoactive plants. ACS Symposium Series, 2009; 1021: 323346.

39. Taïwe GS, Kuete V, Neurotoxicity and neuroprotective effects of African medicinal plants. In toxicological survey of African medicinal plants; Elsevier Inc., 2014; 423-444.

40. Vermillion K, Holguin FO, Berhow MA, Richins RD, Redhouse T, O'Connell MA, Posakony J, Mahajan SS, Kelly SM, Simon JA, Dinoxin B, A withanolide from Datura inoxia leaves with specific cytotoxic activities. Nat Prod., 2011; 74(2): 267-271. 